\title{
Impacts of an invasive seaweed Sargassum hystrix var. fluitans (Børgesen 1914) on the fisheries and other economic implications for the Nigerian coastal waters.
}

\author{
${ }^{1}$ Solarin B. B., ${ }^{2}$ D. A. Bolaji, ${ }^{3}$ O. S. Fakayode and ${ }^{4}$ R.O. Akinnigbagbe \\ ${ }^{1,2,3,4}$ Nigerian Institute for Oceanography and Marine Research, Victoria Island, Lagos, Nigeria.
}

\begin{abstract}
Nigerian coastline and estuarine fishing communities recently witnessed the invasion of seaweed identified as Sargassum hystrix var. fluitans (Børgesen 1914) during a 16 month survey conducted between May 2011 and August 2012. It was observed that the sea weed occurred mainly during the rainy season (May August). The spread and distribution of Sargassum hystrix var. fluitans along the coastal and estuarine fishing communities negatively impacted fishing activities as it limited access to fishing ground, clogged fishing gears mainly mono and multifilament gillnets which resulted in loss of man hours used in clearing the seaweed and preparing the gears for next fishing trips. Floating mass of the seaweed also served as aggregating device and provided food and shelters for fish, shell fishes and juvenile sea turtles. Proximate analysis of nutrient constituent of Sargassum hystrix showed 14.33\% moisture, 6.55\% protein, 1.90\% lipid, 18.5\% ash, 58.72\% carbohydrate and $17.00 \%$ fiber. Using LaMotte spectrophotometer, mineral constituent consisted of 0.48ppm nitrate nitrogen, 170.00ppm potassium and 16.70ppm phosphate which suggested that Sargassum hystrix var. fluitans can provide minerals for the development of other agricultural products of economic importance.
\end{abstract}

Key words: Seaweed, Fishing gear, Nutrient, Minerals and Conservation.

\section{Introduction}

Nigeria has an extensive coastline of $853 \mathrm{~km}$ stretching from the boundary with Benin Republic in the West to Cameroon border in the East. (Fig.1). The area lies in the West Africa sub-region and experience Guinea Current which flows eastward along the western coast of Africa derived from the North Equatorial Counter Current (NECC) and the Canary Current (Henin et al. 1986). The region biodiversity contains diverse assemblage of fish, shell fish (shrimps, crabs, lobster, gastropods and cephalopods), reptiles (sea turtles) and marine mammals (cetaceans) and other living organisms (Dublin-Green and Tobor 1992; Solarin 2010).

Seaweed distribution and diversity has been reported to be in close association with nutrient - rich upwelling's region (King, 2007). John and Lawson (1991) opined that with the exception of Ghana, which experiences upwelling along its coast, the tropical province generally has a low diversity of seaweeds. Ecological factors prevalent in Nigerian coastal waters and indeed in tropical West Africa such as low tidal amplitude, existence of a shallow, permanent thermocline, negligible upwelling phenomenon and lack of natural rocky shore may be reasons for poor seaweed diversity in Nigeria (Dublin-Green and Tobor 1992).

Lee (1999) and Onyema (2007) attributed coastal algal blooms to nutrient load from anthropogenic sources. Bloom conditions have been reported in some of Nigerian waters (Nwankwo et al., 2003a; Nwankwo et al., 2008). Blooms of Microcystis aureginosa, M. flos-aquae and M. wesenbergii were reported in the Lagos Lagoon (Nwankwo, 1993) as well as Ogun river at Iju (Nwankwo, 1993) causing bluish colouration, anoxia, odour, impacting taste to the water (Nwankwo et al., 2003a) and Kuramo lagoon (Nwankwo et al., 2008). Blooms of Trichodesmium thiebautii have also been reported off the Lagos coast (Nwankwo, 1993) during thermocline conditions and more recently a bloom of Bellerochea malleus that caused brownish discolouration off the Light house beach, Lagos (Nwankwo et al., 2004) was documented. Blooms of Anabaena flos-aquae, A. spiroides (cyanobacteria), Cerataulina bergoni, Chaetoceros convolutus, Coscinodiscus centralis (diatoms) and Ceratium furca, C. fusus, C. tripos and Noctiluca scntillans (dinoflagellates) are known to induce harmful effects in waters of south-western Nigeria (Nwankwo, 1993; Nwankwo et al., 2003a, b, Onyema, 2008) Onyema and Nwankwo $(2006,2009)$ reported substratum discolouration in the Lagos lagoon system (implicating Beggiatoa alba and Oscillatoria spp as causative species.

In 1984, Nigeria witnessed massive invasion of its coastal waters by water hyacinth (Eichhornia crassipes (Mart) Solms) (Akinyemiju, 1987; Kusemiju, 1988) and since then it has been spreading rapidly to the riverine villages and towns of Nigeria. In recent times a brownish sea weed has been observed floating and some washed ashore of several coastal beaches and brackish water at different locations in Nigeria.

However, despite considerable interest in research and development of the fisheries of Nigerian waters in recent years, surprisingly little effort has been directed at the associated non-fish resources. Apart from their ecological role, aquatic macrophytes contribute greatly to the economic, scientific, and recreational importance 
of Nigerian water bodies. The ecology, population dynamics and socio-economic importance of the resources are inter-related with other dependent aquatic organisms. Although if present in large quantities, aquatic plants may have adverse effects on navigation, result in high water losses through evapo-transpiration, and provide habitat for vectors of water-borne diseases. In a balanced environment they have recreational, aesthetic and medicinal values.

The study involved identification of the brownish alga, analysis of the proximate composition and mineral constituent as well as the economic implications for Nigerian fisheries and the agricultural sector.

\section{Materials and methods}

Brownish floating seaweed washed ashore on Nigerian coastal beaches was collected between Latitude $6^{\circ} 25^{\prime} 10.47^{\prime \prime} \mathrm{N}$ and $5^{\circ} 52^{\prime} 9.95^{\prime \prime} \mathrm{N}$ and longitude $3^{\circ} 25^{\prime} 9.94 "$ and $4^{\circ} 52^{\prime} 9.95^{\prime \prime}$ (Fig. 1). The collected samples were examined for identification and laboratory analyses were carried out to determine nutritional and mineral constituents. Different identification manuals and materials were consulted for identification (Coston-Clements et al.1991, Tanaka and Fosca, 2003, V.K. Dhargalkar, 2004, Gower et al., 2006 and Guiry and Guiry, 2012). Proximate composition including moisture, protein, fat, ash and carbohydrate were measured according to Association of Official Analytical Chemists (AOAC) (2000).Nutritional and mineral constituents were also determined using LaMotte Spectro Spectrophotometer at the Central laboratory, Nigerian Institute for Oceanography and Marine Research, Lagos. Fishermen encountered during collection of seaweed while landing from fishing trip were interviewed orally to determine impact on fishing activities.

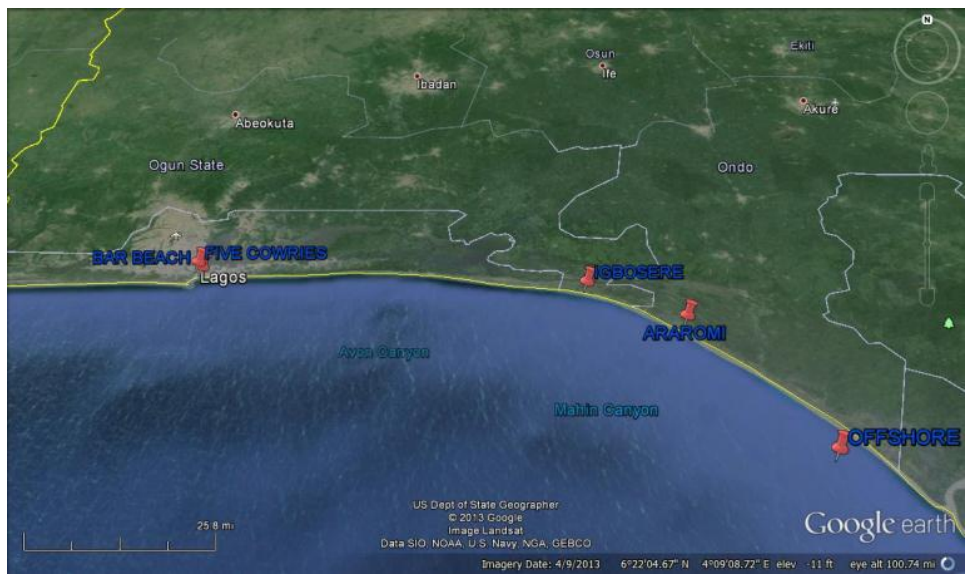

Fig.1: Stations where seaweeds were sited and collected

\section{Result}

The brown seaweed collected was identified as Sargassum fluitans (Børgesen 1914) otherwise referred to as Sargassum hystrix var. fluitans (Guiry and Guiry, 2012). Sargassum fluitans is a brown alga (Class Cyclosporeae: Order Fucales: Family Fucaceae: Genus Sargassum) commonly known as gulfweed, sea holly, or sargassum, they are hyponeustonic and holopelagic which means they are fully adapted to a pelagic existence (Parr, 1939).They are characterized by a brushy, highly branched thallus (stem) with numerous leaf-like blades and berrylike pneumatocysts (floats) (Plate 1). The proximate composition included moisture $14.33 \%$, protein $6.55 \%$, lipid $1.90 \%$, ash $18.5 \%$, carbohydrate $58.72 \%$ and fiber $17.00 \%$. The mineral composition included nitrate nitrogen $0.48 \mathrm{ppm}$, potassium $170.00 \mathrm{ppm}$ and phosphate $16.70 \mathrm{ppm}$. The nutritional and mineral constituents of Sargassum hystrix var. fluitans are presented in Tables 1 and 2 respectively.

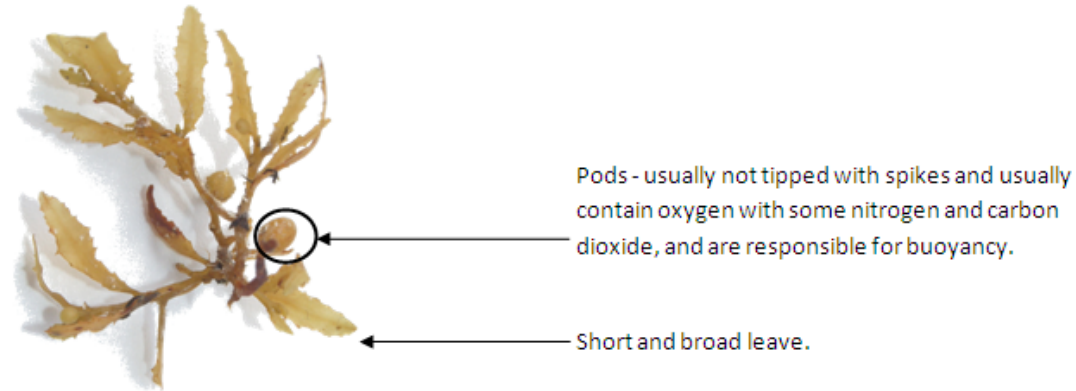

Plate 1: Distinguishing features of Sargassum hystrix var. fluitans (Børgesen 1914) found in Nigerian coastal waters. 
Table 1: Proximate composition of Sargassum hystrix var. fluitans .

\begin{tabular}{|l|l|}
\hline Compound description & Percentage concentration of nutrient (\%) \\
\hline Moisture & 14.33 \\
\hline Protein & 6.55 \\
\hline Lipid & 1.90 \\
\hline Ash & 18.5 \\
\hline Carbohydrate & 58.72 \\
\hline Fiber & 17.00 \\
\hline
\end{tabular}

Table 2: Mineral constituent of Sargassum hystrix var. fluitans .

\begin{tabular}{|l|l|l|l|}
\hline Mineral & Constituent $\mathbf{( p p m )}$ & $\begin{array}{l}\text { Standard Spectrophotometer range } \\
(\mathbf{p p m})\end{array}$ & Remark \\
\hline Nitrate Nitrogen & 0.48 & $0.00-3.00$ & $\begin{array}{l}\text { Within acceptable range of } \\
\text { specification }\end{array}$ \\
\hline Potassium & 170.00 & $0.00-10.00$ & Highly rich in potassium \\
\hline Phosphate & 16.70 & $0.00-70.00$ & $\begin{array}{l}\text { Within acceptable range of } \\
\text { specification }\end{array}$ \\
\hline
\end{tabular}

Fishing gear used by artisanal fishermen and industrial trawl net were observed to have being clogged by the floating mass of seaweed. Different fishing gears used in the area that were impacted included gillnets, beach seine, stownet and trawlnets. As a result of clogging by seaweed cleaning of fishing nets and preparations for fishing trips took longer hours as demonstrated in (Plates 2 and 3).

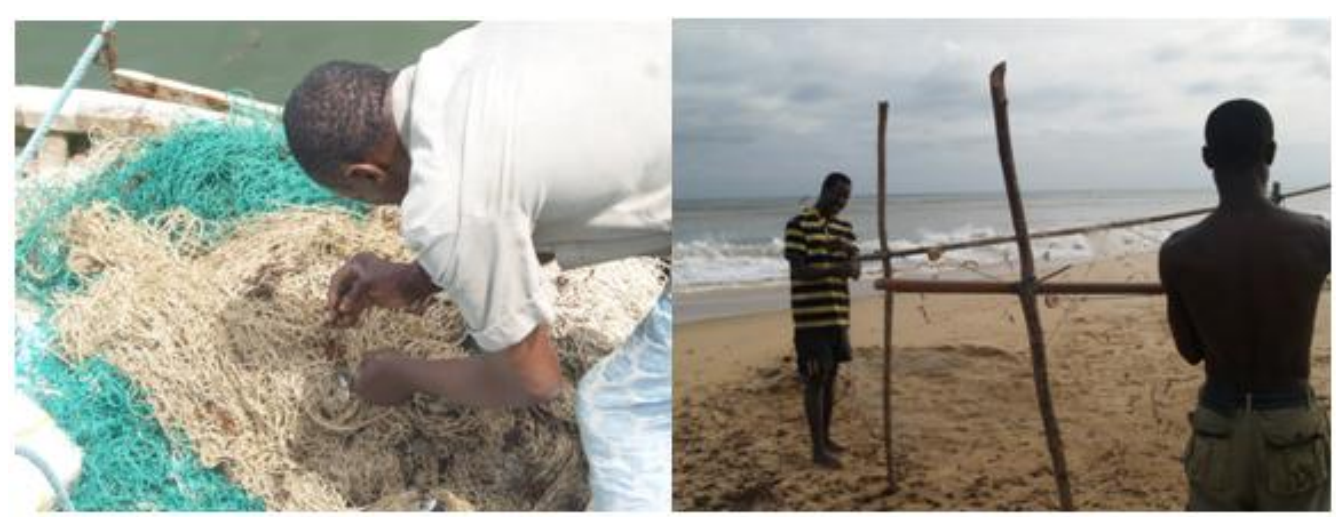

Plate 2: Fishermen removing Sargassum hystrix var fluitans from fishing nets in Lagos and Ondo coastal communities.

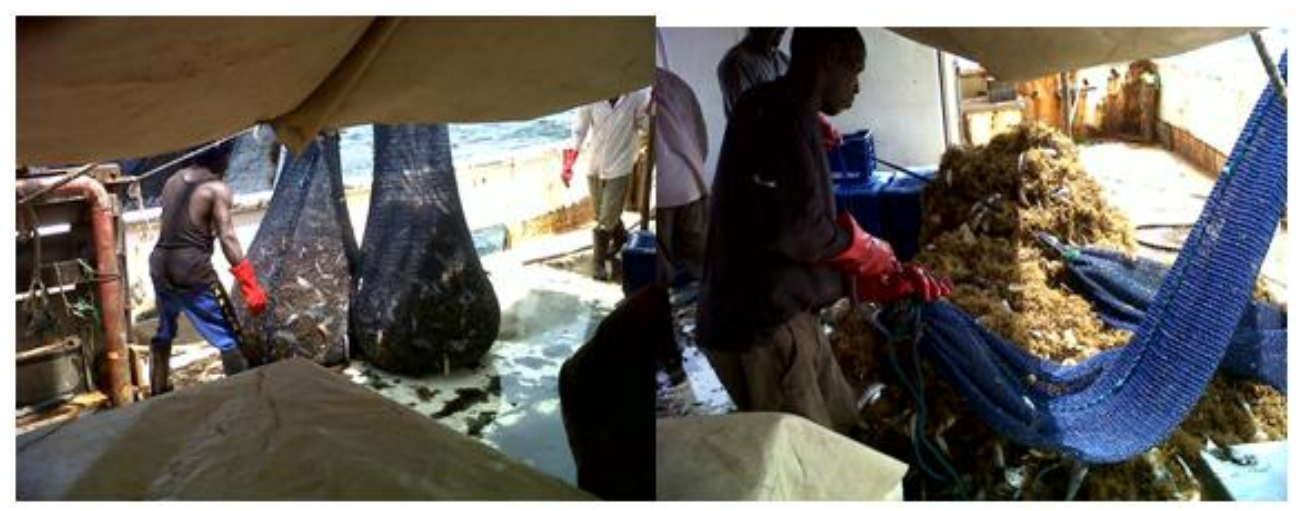

Plate 3: Industrial trawl net filled by Sargassum hystrix var fluitans.

\section{Discussions}

According to Gower et al. (2006) floating Sargassum may be up to several meters in length but are typically much smaller and grow in dense intertwined mats in the Sargasso Sea where the species derived its name. Masses of Sargassum as large as football fields were reported by Tanaka and Fosca (2003) as being deposited by currents and wind on different coastlines around the world. According to Henin et al. (1986) the invasion observed in Nigerian coastal water was under the influence of Guinea Current which flows eastward along the western coast of Africa derived from the North Equatorial Counter Current (NECC). The Canary Current according to Coston-Clements et al. (1991) influenced the movement of pelagic complex of Sargassum 
which comprised primarily of Sargassum natans and S. fluitans in the western North Atlantic. Abowei and Tawari, (2011) reported the presence of Sargassum vulgar alone in Nigeria. Gheskiere et al. (2006) reported the spread of Sargassum along the beach of Galveston Island, Texas each year from May to August in two consecutive years 2011 and 2012. A similar occurrence was observed in Nigerian coastal water during the period of study.

\section{Economic Impact of Sargassum hystrix var fluitans in Nigeria}

Sargassum hystrix var fluitans had invaded both brackish and marine coastal waters in Nigeria with patches on the beach and also impeded navigation and fishing activities by artisanal and the industrial fishermen respectively. The clogging of the fishing nets mainly monofilament and multifilament resulted in loss of man hours spent in removing the weed from the net in preparation for the next fishing trip. Although gillnets were sited mainly during this survey, several other fishing gears used were also impacted by clogging based on their operational methods including beach seine, purse seine, stownet and trawl nets. Low catch was reported by the fishermen who nicknamed the weed in local parlance as "Irun Imu Ijoba" (literally meaning government moustache) in addition to other nomenclatures such as gulfweed, sea holly, or Sargassum. Eklof et al. (2006) which concluded that in areas naturally lacking vegetations such as sand banks, presence of seaweed farms impacted positively on fisheries production by increasing fish catches of certain species. However, limited accessibility to fishing ground and clogging of nets might be responsible for low fish catch reported by the fishermen as against low fish productivity since masses of Sargassum covering large area of water will normally act as fish aggregating device (FAD) providing food, shelter and assemblage for several ecological communities.

In the past couple of years, changes in the natural climate and weather patterns across the North Atlantic appeared to have allowed Sargassum weed to grow more. Such changes are related to large atmosphere and ocean circulation changes that originate across the planet in the eastern tropical Pacific Ocean and in the Arctic Ocean. In these patches of Sargassum weed, found at the surface of the ocean, create very interesting biological museum. Floating mass of Sargassum hystrix var fluitans formed important habitat for fishes and invertebrates providing home for many animals. Mats of seaweed also acted as refuge for several juvenile fishes such as chubs, dolphin fish, triple tail fish, trigger fish, flying fish and pipefish. Large predatory species associated with the Sargassum habitat include jacks, dolphins (Coryphaenidae), barracudas (Sphyraenidae), mackerels and tunas (Scombridae), swordfish (Xiphiidae), and billfishes (Istiophoridae) (Gibbs and Collette, 1959; Stephens, 1965; Dooley, 1972; Fedoryako, 1980; Carr, 1986). Juvenile turtles used the floating mats as protection and feeding (Hong-Yu et al. 2010).

Patches of Sargassum weed were also observed to be beneficial for pelagic seabirds that fed on the fish that hung out beneath the patches. As indicators of climate change; they can be used to study diversity patterns and were particularly useful for planning conservation and sustainable use of inshore marine resources (John and Lawson, 1991; Jennings et al., 2001).

The earliest record of seaweeds utilization generally dated about 13,000 years ago (Abowei and Tawari, 2011) Seaweeds have been included in folk medicine for many thousands of years in Japan, China, Egypt, India and South Korea (NAAs, 2003; Teas, 2005, Hong 2010). They are excellent sources of vitamins, proteins, lipids and amino acids. Many seaweed species were used as food throughout Asia and Pacific region (Abowei and Tawari, 2011).

The proximate composition of nutrient and mineral constituent showed that Sargassium is nutritionally rich with acceptable level of minerals which have been found to enhance plant germination through production of liquid fertilizer (Sivasankari et al., 2006; Trono JR., 1999). Although, this study didn't determine the toxic substances in Sargassum fluitan in order to advice on direct consumption but the observed nutrition and mineral constituents agreed with Abowei and Tawari (2011) which suggested that they could be consumed directly by humans and be used in medicine, pharmaceuticals, industrial production as well as agricultural processes. Seaweeds extracts and fractions have also been reported to be a rich source of antioxidants and different types of antioxidants have been isolated from various species of seaweeds (Fujimoto and Kaneda, 1984; Cahyana et al., 1992; Nagai and Yukimoto, 2003; Huang and Wang, 2004; Wang et al., 2009; Mancini-Filho et al., 2009; Rioux et al., 2010; Hu et al., 2010).

The protein content of Sargassum hystrix var fluitans recorded were $6.55 \%$ which was slightly higher than Sargassum polycystum (5.40\%) reported by Matanjun et al. 2009 but were within the ranges of brown seaweeds (3-15\% DW) and red and green seaweeds (10-47\% DW) (Arasaki and Arasaki 1983; Darcy-Vrillon 1993; Mabeau and Fleurence 1993). Sargassum hystrix var fluitans fiber recorded was $17.00 \%$ which was lower to the total dietary fiber reported in S. polycystum (39.67\%). The total dietary fiber content are within the range of other seaweeds (Jiménez-Escrig and Sánchez-Muniz 2000; Mabeau and Fleurence 1993) and higher than most terrestrial plants. According to Matanjun et al. 2009 soluble fibers appear to be a good potential functional food ingredient for lowering cholesterol and glycaemic index for prevention of metabolic syndromes. 
Carbohydrate (58.72\%), Moisture (14.33\%) and Lipid (1.90\%) obtained were respectively higher, , than 33.49\%, 9.95\% and $0.29 \%$ reported by Matanjun et al. 2009 but ash (18.5\%) was lower than $42.4 \%$. According to Ortega-Calvo et al. (1993) mineral content of seaweeds was observed to be higher than that of land plants, a unique property that make sea weed a suitable replacement for land plants in fish feed production, since sea weed culturing need low investments and analyses of Sargassum hystrix var fluitans shows that it consist of 0.48ppm Nitrate Nitrogen, Potassium 170.00ppm and Phosphate 16.70ppm.

Sargassum is also beneficial on the beach front as it provides shelter and food for organisms once on the beach and also protects sand from wave erosion by trapping sand from wind erosion (Gheskiere et al., 2006; Orr et al., 2005; Roberts and Poore, 2005; Ryland, 1974; Tanaka and Fosca, 2003).

In area where Sargassum have constituted a big hazard one method of dealing with the problem wasthe use of mechanical equipment to rake the material which was deposited at the base of the dunes (Bruun, 1983; Conaway and Wells, 2005; Dugan et al., 2003; Gheskiere et al., 2006; Nordstrom et al., 2006) but the weeds can also be used as natural fertilizer in agricultural processes.

\section{Acknowledgements}

We are grateful to staffs of Fish Technology Laboratory and Central Laboratory of Nigerian Institute for Oceanography and Marine Research (NIOMR) for helping with laboratory analysis and procedures as well as all the fishermen that willingly gave information during our studies.

\section{References}

[1]. Abowei J.F.N. and C.C. Tawari, (2011). A Review of the Biology, Culture, Exploitation and Utilization Potentials Seaweed Resources: Case Study in Nigeria. Research Journal of Applied Sciences, Engineering and Technology, 3(04): 290-303.

[2]. Akinyemiju, O.A. (1987). Invasion of Nigerian waters by water hyacinth J. Aquat. Plant Manage. $25: 24-26$.

[3]. AOAC (2000) Official Methods of Analysis of AOAC International, 17th edn. AOAC International, Md., USA. 2000pp.

[4]. Arasaki S and Arasaki T (1983) Low Calorie, High Nutrition Vegetable from the sea. Japan Pub, Tokyo. In: Brody T (1999) Nutritional biochemistry, 2nd edn. Academic Press, London. 32-52pp.

[5]. Bruun, P., 1983. Beach scraping - is it damaging to beach stability? Coastal Engineering, 7, 167-173.

[6]. Cahyana A. H., Shuto Y. and Kinoshita Y, (1992). Pyropheophytin as an antioxidative substance from the marine alga, Arame (Eiseniabicyclis). Biochem. Biophys. Res. Commun., 56, 1533-1535.

[7]. Carr, A. (1986). Rips, FADS, and little loggerheads. BioScience 36(2):92-100.

[8]. Conaway, C.A. and Wells, J.T. (2005). Aeolian dynamics along scraped shorelines, Bogue Banks, North Carolina. Journal of Coastal Research, 21, 242-254.

[9]. Coston-Clements, L., L.R. Settle, D.E. Hoss and F.A. Cross. 1991. Utilization of the Sargassum habitat by marine invertebrates and vertebrates - a review. NOAA Technical Memorandum NMFS-SEFSC-296, 32 p.

[10]. Darcy-Vrillon, B (1993). Nutritional aspects of the developing use of marine macroalgae for the human food industry. Int. J. Food Sc. Nutr. 44:23-35

[11]. Dhargalkar V.K. (2004). National Institute of Oceanography, Dona Paula, Goa. 403004 Disclaimer: The authors are responsible for the contents of this manual First Edition: March 2004. Pg. 42.

[12]. Dooley, J.K. (1972). Fishes associated with the pelagic sargassum complex, with a discussion of the sargassum community. Contrib. Mar. Sci. 16:1-32.

[13]. Dublin-Green, C. O. and Tobor, J. G. (1992). Marine Resources and activities in Nigeria. NIOMR Technical paper No. 84. 25p.

[14]. Dugan, J.E., Hubbard, D.M., Mccrary, M.D. and Pierson, M.O., (2003). The response of macrofauna communities and shorebirds to macrophyte wrack subsidies on exposed sandy beaches of southern California. Estuarine, Coastal and Shelf Science, 58, 25-40.

[15]. Eklof, J.S., M. de la Torre-Castro, C. Nilsson and P. Ronnback, 2006. How seaweed farms influence local fishery catches in a seagrass do dominated setting in Chwaka Bay, Zanzibar. Aquat. Living Resour., 19:137-147.

[16]. Fedoryako, B.I. 1980. The ichthyofauna of the surface waters of the Sargasso Sea southwest of Bermuda. J. Ichthyol. 20(4):1-9.

[17]. Fujimoto K. and Kaneda T. (1984). Separation of antioxygenic (antioxidant) compounds from marine algae. Hydrobiologia, 116/117: 111-113

[18]. Gheskiere, T., Magda, V., Greet, P. and Steve, D., 2006. Are strandline meiofaunal assemblages affected by a once-only mechanical beach cleaning? Experimental findings. Marine Environmental Research, 61, 245-264.

[19]. Gibbs, R.M., Jr. and B.B. Collette. 1959. On the identification. distributions, and biology of the dolphins, Coryphaena hippurus and C. equisetis. Bull. Mar. Sci. Gulf and Carib. 9:117-152.

[20]. Gower, J., Hu, C., Borstad, G. and King, S., 2006. Ocean color satellites show extensive lines of floating Sargassum in the Gulf of Mexico. IEEE Transactions on Geoscience and Remote Sensing, 44, 3619-3625. 45

[21]. Guiry, M.D. and Guiry, G.M. 2012. AlgaeBase. World-wide electronic publication, National University of Ireland, Galway. http://www.algaebase.org; searched on 08 November 2012.

[22]. Henin, C., P. Hisard, and B. Piton, 1986: Observations hydrologiques dans l'ocean Atlantique Equatorial, Ed. ORSTOM, FOCAL, 1, 1-191.

[23]. Hong-Yu Luo, Bin Wang, Chun-Guang Yu, You-le Qu and Chuan-ling Su, (2010). Evaluation of antioxidant activities of five selected brown seaweeds from China. Journal of Medicinal Plants Research Vol. 4(18), pp. 2557-2565.

[24]. Hu T, Liu D, Chen Y, Wu J and Wang S (2010). Antioxidant activity of sulfated polysaccharide fractions extracted from Undaria pinnitafida in vitro. Int. J. Biol. Macromol., 46: 193-198.

[25]. Huang H.L. and Wang BG (2004). Antioxidant Capacity and Lipophilic Content of Seaweeds Collected from the Qingdao Coastline. J. Agric. Food Chem., 52: 4993-4997.

[26]. Jennings, S., M.J. Kaiser and J.D. Reynolds. (2001). Marine Fisheries Ecology. Blackwell Science, Oxford, ISBN- 13: 978 0632050987. 417pp.

[27]. Jiménez-Escrig A. and Sánchez-Muniz F. J. (2000) Dietary fibre from edible seaweeds: chemical structure, physiochemical properties and effects on cholesterol metabolism. Nutr Res 20:585-598. 
[28]. John, D.M and G.W. Lawson, (1991). Littoral Ecosystems Tropical Western Africa. In: Mathieson, A.C. and D.H. Nienhuis (Eds.). Intertidal and Littoral Ecosystems of the World 24. Elsevier, Amsterdam, pp: 297 - 322

[29]. King, M., 2007. Fisheries Biology, Assessment and management. Fishing news Books, Blackwell Scientific Publications Ltd., Oxford. ISBN - 13: $978-1-4051-5831-2$, 400pp.

[30]. Kusemiju, k. (1988). Strategies for effective management of water hyacinth in the creeks and Lagoons of South western Nigeria In: Oke, K.L; A.M.A Imevbore and T.A Farri Op. Cit. 39-45

[31]. Lee, R.E. (1999). Phycology. Cambridge University Press, New York. 614pp.

[32]. Mabeau S. and Fleurence J (1993) Seaweed in food products: biochemical and nutritional aspects. Trends Food Sci Technol 4:103107.

[33]. Mancini-Filho J., Novoa A.V., González A.E., de Andrade-Wartha E.R., de Oe Silva A.M., Pinto J.R. and Mancini D.A. (2009). Free phenolic acids from the seaweed Halimeda monile with antioxidant effect protecting against liver injury. Z. Naturforsch. C., 64: 657-663.

[34]. Matanjun P, Mohamed S, Mustapha N. M., Muhammad K. and Ming C. H. (2008) Antioxidant activities and phenolics content of eight species of seaweeds from north Borneo. J Appl Phycol DOI 10.1007/s10811-007-9264-6.

[35]. NAAS, 2003. Seaweed Cultivation and Utilization. Policy Paper 22. National Academy of Agricultural Sciences, India, pp: 1-6. Retrieved from: http://www.naasindia.org/Policy\%20Papers/pp22.pdf.

[36]. Nagai T. and Yukimoto T (2003). Preparation and functional properties of beverages made from sea algae. Food Chem., 81: $327-$ 332 .

[37]. Nordstrom, K., Jackson, N., Klein, A.H.F., Sherman, D.J. and Hesp, P.A., (2006). Offshore aeolian transport across a low foredune on a developed barrier island. Journal of Coastal Research, 22, 1260-1267.

[38]. Nwankwo, D.I. (1993). Cyanobacteria bloom species in coastal waters of South-Western Nigeria. Archiv Hydrobiologie Supplement. 90: 553-542.

[39]. Nwankwo, D.I., Onyema, I.C. and Adesalu, T.A.(2003a). A survey of harmful algae in coastal waters of south-western Nigeria. Journal of Nigerian Environmental Society. 1(2). $241-246$.

[40]. Nwankwo, D.I., Onyema, I.C., Adesalu, T.A., Olabode, R.J., Osiegbu, G.O. and Owoseni, T.I. (2003b). Additions to a Preliminary Checklist of Planktonic Algae in Lagos lagoon, Nigeria. Journal of Science Technology and Environment. 3(1): 8 - 12.

[41]. Nwankwo, D.I., Onyema., I.C, Labiran, C.O., Otuorumo, O.A.; Onadipe, E.I.;, Ebulu, M.O. and Emubaiye, N. (2004). Notes on the observations of brown water discolouration off the light house beach, Lagos, Nigeria. Discovery and Innovation. 16 (3). $111-116$.

[42]. Nwankwo, D.I., Owoseni, T.I., Usilo, D.A., Obinyan I., Uche, A.C. and Onyema, I.C. (2008). Hydrochemistry and plankton dynamics of Kuramo lagoon. Life Science Journal. 5 (3): 50 - 55.

[43]. Onyema, I.C. (2007). Mudflat microalgae of a tropical bay in Lagos, Nigeria. Asian Journal of Microbiology, Biotechnology and Environmental Sciences. 9 (4): $877-883$.

[44]. Onyema, I.C. (2008). Phytoplankton biomass and diversity at the Iyagbe lagoon Lagos, Nigeria. University of Lagos, Akoka. Department of Marine Sciences. PhD Thesis ,266pp

[45]. Onyema, I.C. and Nwankwo, D.I. (2006). The epipelic assemblage of a polluted estuarine creek in Lagos, Nigeria. Pollution Research. 25(3): 459 - 468.

[46]. Onyema, I.C. and Nwankwo, D.I. (2009). An Incidence of Substratum Discolouration in a Tropical West African Lagoon. New York Science Journal 2(2): 51-60.

[47]. Orr, M., Zimmer, M., Jelinski, D.E. and Mews, M., (2005). Wrack deposition on different beach types: spatial and temporal variation in the pattern of subsidy. Ecology, 86, 1496-1507. 46

[48]. Ortega-Calvo J. J., Mazuelos C., Hermosin B. and Sáiz-Jiménez C. (1993) Chemical composition of Spirulina and eukaryotic algae food products marketed in Spain. J Appl Phycol 5:425-435

[49]. Parr, A.D. 1939. Quantitative observations on the pelagic Sargassum vegetation of the western North Atlantic. Bull.Bingham Oceanogr. Coll., Yale Univ. 6(7):1-94.

[50]. Rioux L. E., Turgeon S. L. and Beaulieu M. (2010). Structural characterization of laminaran and galactofucan extracted from the brown seaweed Saccharina longicruris. Phytochemistry, 71:1586-1595.

[51]. Roberts, D.A. and Poore, A.G.B., (2005). Habitat configuration affects colonisation of epifauna in a marine algal bed. Biological Conservation, 127, 18-26.

[52]. Ryland, J.S., (1974). Observations on Some Epibiont of Gulf-Weed, Sargassum natans (L.) Meyen. Journal of Experimental Marine Biology and Ecology, 14, 17-25.

[53]. Sivasankari, S., Venkatesalu, V., Anantharaj, M. and Chandrasekaran, M., (2006). Effect of seaweed extracts on the growth and biochemical constituents of Vigna sinensis. Bioresource Technology, 97, 1745-1751.

[54]. Solarin, B. B. (2010) Status of small cetaceans in Nigeria. Paper presented at the meeting of the Scientific Sub- Committee of International WhalingCommittee (IWC) at Agadir, Morocco June 2010 SC/62/SM12 :6 - 12

[55]. Stephens, W.M. (1965). Summer cruise to the Sargasso Sea. Sea Frontiers 11:108-123.

[56]. Tanaka, M.O. and Fosca, P.P.L., 2003. Spatial scaling in the distribution of macrofauna associated with Sargassum stenophyllum (Mertens) Martius: analysis of faunal groups gammarid life habits, and assemblage structure. Journal of Experimental Marine Biology and Ecology, 293, 1-22.

[57]. Teas, J., (2005). Dietary Brown Seaweeds and Human Health Effects. In: Critchley, A.T., O. Masao and M. Danilo (Eds.), Seaweed Resources. Publisher Expert Centre for Taxonomic Identification, Amsterdam. 31pp.

[58]. Trono Jr., G.C., (1999). Diversity of the seaweed flora of the Philippines and its utilization. Hydrobiologia, Vol. 398-399: 1-6.

[59]. Wang BG, Zhang WW, Duan XJ, and Li XM (2009). In vitro antioxidative activities of extract and semi-purified fractions of the marine red alga, Rhodomela confervoides (Rhodomelaceae). Food Chem., 113:1101-1105. 